\title{
PENGARUH ROA, DER, CR, INFLASI DAN KURS TERHADAP RETURN SAHAM (STUDI KASUS INDUSTRI MAKANAN DAN MINUMAN YANG TERDAFTAR DI BEI PERIODE 2008-2012)
}

\section{(The Effect of ROA, DER, CR, Inflation and Exchange Rate on Stock Return-Case on Food and Bevarage Industry Which Listed at BEI in the Period of 2008-2012)}

\author{
Meri Arisandi ${ }^{1}$
}

\begin{abstract}
${ }^{1}$ Mahasiswa Program Pascasarjana Program Magister Manajemen, Pascasarjana Universitas Jambi.
\end{abstract}

\begin{abstract}
The objectives of this research to analyze the influence of ROA, DER, CR, inflation and exchange rate to stock return on Food and Baverage industry that listed on Indonesian Stock Exchange in the period of 2008-2012.The number of population is 19 companiesand eligablesample is 16 companies. Analyze technique that use to analyze data is multiple linier regression. Analyses result showed that the partial results of Return On Asset (ROA), inflation and exchange rate variables has significant influence to stock return in other hand DER and $C R$ has insignificantinfluenced to stock return on Food and Baverage industry.
\end{abstract}

\begin{abstract}
ABSTRAK
Tujuan penelitian ini adalah menganalisis pengaruh ROA, DER, CR dan tingkat inflasi terhadap return saham pada Industri Makanan Minuman yang terdaftar pada Bursa Efek Indonesia periode Tahun 2008-2011. Jumlah populasi adalah 19 perusahaan, dan sampel yang layak dipilih adalah 16 perusahaan. Teknik analisis yang digunakan menganalisis data adalah Regressi Multiple. Hasil analisis menunjukkan bahwa ROA, tingkat inflasi, dan nilai tukar mempunyai hubungan parsial yang signifikan kepada return saham, sebaliknya DER dan CR mempunyai pengaruh yang tidak signifikan terhadap return saham.
\end{abstract}

Keyword : On Asset (ROA), Debt to Equity Ratio (DER), Current Ratio (CR), Inflation, exchange rate, stock Return

Alamat korespondensi.e-mail: Meriarisandi09@gmail.com

\section{PENDAHULUAN}

\subsection{Latar Belakang}

Pasar modal merupakan lembaga keuangan yang berperan sebagai sarana memobilisasi dana yang bersumber dari masyarakat ke berbagai sektor yang melakukan investasi.Syarat utama yang diinginkan oleh para investor untuk bersedia menyalurkan dananya melaluipasar modal adalah perasaan aman akan investasinya. Sebagai dasar penilaian kinerja perusahaan,laporan keuangan perusahaan yang go public sangat penting.

Kegiatan investasi merupakan suatu kegiatan menempatkan dana padasatu atau lebih asset selama periode tertentu dengan harapan dapatmemperoleh pendapatan atau peningkatan 
atas nilai investasi awal(modal), bertujuan untuk memaksimalkan hasil (return), diharapkan dalam batas risiko yang dapat diterima untuk tiap investor(Jogiyanto, 2000). Namun banyak hal yang harus dipertimbangkan dalammemilih saham yang akan diinvestasikan. Tujuan utama dari investasi adalah untuk memperoleh keuntungan (return).Para investormenggunakan berbagai cara untuk memperoleh return yang diharapkan,baik melalui analisis sendiri terhadap perilaku perdagangan saham, maupundengan memanfaatkan saran yang diberikan oleh para analis pasar modalseperti broker, dealer, manajer investasi dan lainlain.

Menurut Ang (1997) dalam Gunawan (2012) ada dua faktor yang mempengaruhi return suatu investasi.Pertama, faktor internal perusahaan seperti kualitas dan reputasi manajemennya, struktur permodalannya, struktur hutang perusahaan, dan sebagainya. Kedua adalah menyangkut faktor eksternal,misalnya pengaruh kebijakan moneter dan fiskal, perkembangan sektor industrinya, kondisi ekonomi ekonomi misalnya terjadinya inflasi, dan sebagainya.

Faktor internal dapat dilihat dari analisis fundamental.Analisis fundamental yang berkaitan dengan kinerja keuangan perusahaan yang tampak pada laporan keuangan.Penelitian ini meliputi analisis rasio profitabilitas yang diwakili oleh Return on Asset (ROA), analisis rasio solvabilitas yang diwakili Debt to Equity Ratio (DER) dan analisis rasio likuiditas yang diwakili oleh Current Ratio (CR).Faktor yang mempengaruhi return saham yang kedua adalah faktor eksternal, salah satunya Kondisi Ekonomi. Tandelin, Eduardus (2001) menyatakan bahwa Prospek keuntungan (return) yang dihasilkan perusahaan dipengaruhi pula oleh keadaan ekonomi.Maka dari itu seorang investor juga harus memperhitungkan variabel kondisi ekonomi yang mempengaruhi kemampuan perusahaan untuk menghasilkan keuntungan.Faktor Kondisi ekonomi yang digunakan dalam penelitian ini berupa nilai tukar uang (kurs) dan tingkat inflasi yang terjadi di Indonesia. Ketika melakukan investasi dalam bentuk saham, seorang investor pasti akan membeli saham yang efisien yang dapat memberikan return saham yang maksimal serta mempunyai nilai risiko yang minimal. Investor tentu tidak akan memilih saham yang tidak memberikan return yang maksimal dan mengandung nilai risiko yang cukup tinggi. Harga suatu saham dapat naik dapat pula turun.Hal tersebut sepenuhnya harus dipahami oleh investor. Oleh karena itu seorang investor yang akan berinvestasi dalam saham harus memperhatikan pula keadaan inflasi maupun nilai tukar uang (kurs).

Obyekdalam penelitian ini adalah Industri makanan dan minuman yang terdaftar di Bursa Efek Indonesia. Sektor ini dipilih karena merupakan salah satu industri yang cenderung diminati oleh investor sebagai salah satu target investasinya, dikarenakan industri makanan dan minuman saat ini sangat digemari oleh masyarakat Indonesia karena sesuai dengan pola hidup masyarakat. Terbukti meski terkena imbas krisis ekonomi global sekalipun, seperti pada Tahun 2008-2009 lalu, industri ini tetap bisa tumbuh. Tahun 2008 misalnya, industri ini masih bisa tumbuh 2,34\%, dan Tahun 2009 kembali melonjak hingga 11,22\% dengan volume penjualan hingga Rp 555 triliun. Sepanjang Tahun 2012 pasar industri makanan dan minuman nyaris tak pernah sepi, bahkan terus meningkat seiring laju pertumbuhan penduduk di Tanah Air yang kini telah mencapai lebih dari 230 juta jiwa. Bukan hanya bahan makanan dasar, kebutuhan food ingredients atau bahan-bahan untuk campuran makanan olahan juga terus meningkat, bahkan sebagian harus diimpor. Pasar Indonesia kian banyak jadi incaran, termasuk para pelaku usaha asing.Perilaku konsumsi dan populasi penduduk besar, selalu menjadi incaran bagi para pelaku usaha. Dengan jumlah penduduk yang besar di antara negara-negara Asean, Indonesia juga telah lama menjadi sasaran empuk berbagai industri. Tak terkecuali industri makanan dan minuman olahan. Apalagi tingkat permintaannya nyaris tak 
pernah surut. Bahkan di tengah krisis ekonomi sekalipun, permintaan produk makanan dan minuman tetap tak pernah sepi. Selama lima tahun terakhir, pertumbuhan konsumsi makanan olahan mencapai $41 \%$ (Anonim, 2012).

Berbagai penelitian yang pernah dilakukan terkait dengan faktor - faktor diatas juga mengindikasikan hasil yang tidak konsisten. Subalno (2009) dan Prihantini, Ratna (2009) menyatakan bahwa ROA berpengaruh signifikan terhadap variabel perubahan return saham. Hal ini berbeda dengan hasil penelitian Arista,D. (2012), Prasetio, W. A. (2012), dan Budialim, G. (2013) yang menyatakan bahwa ROA tidak berpengaruh signifikan terhadap return saham.Penelitian Prasetio, W.A. (2012), Arista, Desy (2012), Prihantini, R. (2009) menyatakan bahwa DER berpengaruh signifikan terhadap return saham. Hal ini berbeda dengan hasil penelitian yang dilakukan oleh Budialim, G. (2013) yang menunjukkan bahwa DER t(2012), dan Prihantini, R. (2009) yang menyatakan bahwaCR berpengaruh signifikan terhadap return saham. Hal ini berbeda dengan hasil penelitian yang dilakukan oleh Budialim, G. (2013) menunjukkan bahwa CR tidak berpengaruh signifikan terhadap return saham.Penelitian Prasetio, W. A. (2012), dan Prihantini, R. (2009) yang menyatakan bahwa CR berpengaruh signifikan terhadap return saham. Hal ini berbeda dengan hasil penelitian yang dilakukan oleh Budialim, G. (2013) menunjukkan bahwa CR tidak berpengaruh signifikan terhadap return saham.

Penelitian Prihantini, R. (2009) menyatakan bahwa Inflasi berpengaruh signifikan terhadap return saham. Hal ini berbeda dengan hasil penelitian yang dilakukan oleh Sodikin, A. (2007) dan Prasetio, W. A. (2012) menunjukkan bahwa Inflasi tidak berpengaruh signifikan terhadap return saham.Penelitian Prihantini, R., (2009) menyatakan bahwa Kurs berpengaruh signifikan terhadap return saham. Hal ini berbeda dengan hasil penelitian yang dilakukan oleh Sodikin, A. (2007), Nasir, A. dan Mirza,A. dan Prasetio, W. A. (2012) yang menunjukkan bahwa Kurs tidak berpengaruh signifikan terhadap return saham.

Berdasarkan penelitian terdahulu terjadi fenomena perbedaan kesimpulan hasil penelitian (research gap), adanya fenomena bisnis yakni perubahan return saham Industri Makanan dan Minuman yang terjadi pada periode 2008 s.d 2012,maka penulis melakukan penelitian ini diberikan judul "Pengaruh ROA, DER, CR,Inflasi, dan Kurs terhadap Return Saham"(Studi Kasus SahamIndustri Makanan dan Minuman yang Terdaftar di BEI Periode 2008 s.d 2012).

\subsection{TujuanPenelitian}

1) Untuk menjelaskan signifikansi secara simultan pengaruh ROA, DER, CR, Inflasidan kurs terhadap Return Saham Industri Makanan dan Minuman di Bursa Efek Indonesia Periode 2008 s.d. 2012.

2) Untuk menjelaskan signifikansi secara parsial pengaruh ROA, DER, CR, Inflasi dan Kurs terhadap Return Saham Industri Makanan dan Minuman di Bursa Efek Indonesia Periode 2008 s.d. 2012. 


\section{TINJAUAN PUSTAKA}

\subsection{Pasar Modal}

Pasar Modal merupakan pasar untuk berbagai instrumen keuangan (sekuritas) jangka panjang yang bisa diperjualbelikan, dalam bentuk hutang maupun modal sendiri, baik yang diterbitkan oleh pemerintah, publik authorities, maupun pihak swasta (Husnan, S. 2009).

\subsection{Investasi}

Investasi pada hakikatnya merupakan penempatan sejumlah dana pada saat ini dengan harapan untuk memperoleh keuntungan dimasa mendatang. Umumnya investasi dibedakan menjadi dua yaitu investasi pada asset-aset financial (financial assets) dan investasi pada asetaset rill (real assets). Investasi pada aset-aset finansial dilakukan di pasar uang, misalnya berupa sertifikat, deposito, commercial paper, surat berharga pasar uang dan lainnya. Investasi dapat pula dilakukan di pasar modal, misalnya berupa saham, obligasi, waran, opsi dan lain-lain (Halim, A. 2005).

\subsection{Return Saham}

Menurut Jogiyanto (2000) Return merupakan hasil yang diperoleh dari investasi. Returndapat dibedakan menjadi dua yaitu:returnrealisasi yang sudah terjadi dan return ekspektasi yang belum terjadi namun diharapkan dapat terjadi dimasa mendatang. Return realisasi merupakan return yang telah terjadi. Return realisasi penting karena digunakan sebagai salah satu pengukur kinerja perusahaan dan dihitung berdasarkan data historis. Return ekspektasi adalah return yang diharapkan akan diperoleh oleh investor dimasa mendatang.

\subsection{ROA dan Hubungannya dengan Return Saham}

Return on Assets (ROA) menggambarkan kinerja keuangan perusahaan dalam menghasilkan laba bersih dari aktiva yang digunakan untuk operasional perusahaan. ROA digunakan untuk mengetahui kinerja perusahaan berdasarkan kemampuan perusahaan dalam mendayagunakan jumlah aset yang dimiliki, ROA akan dapat menyebabkan apresiasi dan depresiasi harga saham. Kinerja keuangan perusahaan dalam menghasilkan laba bersih dari aktiva yang digunakan, akan berdampak pada pemegang saham perusahaan. ROA yang semakin bertambah menggambarkan kinerja perusahaan yang semakin baik dan para pemegang saham akan mendapatkan keuntungan dari dividen yang diterima semakin meningkat, atau semakin meningkatnya harga maupun return saham (Sutrisno, 2009).

\subsection{DER dan Hubungannya dengan Return Saham}

Debt to Equity Ratio (DER) mencerminkan kemampuan perusahaan dalam memenuhi seluruh kewajibannya yang ditunjukkan oleh berapa bagian dari modal sendiri yang digunakan untuk membayar hutang.DER menunjukkan imbangan antara beban hutang dibandingkan modal sendiri.DER juga memberikan jaminan tentang seberapa besar hutang perusahaan dijamin modal sendiri. Pemilihan alternatif penambahan modal yang berasal dari hutang karena pada umumnya hutang memiliki beberapa keunggulan (Brigham and Gapenski, 1997). Keunggulan pertama, bunga mengurangi pajak sehingga biaya hutang 
rendah;kedua,kreditur memperoleh return terbatas sehingga pemegang saham tidak perlu berbagi keuntungan ketika kondisi bisnis sedang maju;ketiga, kreditur tidak memiliki hak suara sehingga pemegang saham dapat mengendalikan perusahaan dengan penyertaan dana yang kecil. Sesuai dengan EBIT-EPS Analysis (Gitman, 1994 dalamPrihatin, Ratna(2009) bila biaya bunga hutang murah maka perusahaan akan lebih beruntung menggunakan sumber modal berupa hutang yang lebih banyak karena menghasilkan laba per saham yang makin banyak. Penggunaan hutang yang makin banyak yang dicerminkan oleh debt ratio (rasio antara hutang dengan total aktiva) yang makin besar, pada perolehan laba sebelum bunga dan pajak (EBIT) yang sama, akan menghasilkan laba per saham yang lebih besar. Jika laba per saham meningkat, akan berdampak pada meningkatnya harga saham atau return saham, sehingga secara teoritis DER akan berpengaruh positif pada return saham.

\subsection{CR dan Hubungannya dengan Return Saham}

Current Ratio yang rendah akan menyebabkan penurunanharga pasar dari harga saham yang bersangkutan. Sebaliknya Current Ratioterlalu tinggi juga belum tentu baik, karena pada kondisi tertentu hal tersebutmenunjukkan banyak dana perusahaan yang menganggur (aktivitas sedikit)yang akhirnya dapat mengurangi kemampuan laba perusahaan. CurrentRatio yang tinggi dapat disebabkan adanya piutang yang tidak tertagihdan persediaan yang belum terjual, yang tentunya tidak dapat digunakansecara cepat untuk membayar hutang. Disisi lain perusahaan yang memilikiaktiva lancar yang tinggi akan cenderung memiliki aset lain yang dapatdicairkan sewaktu-waktu tanpa mengalami penurunan nilai pasarnya(menjual efek). Perusahaan dengan posisi tersebut sering kali terganggulikuiditasnya, sehingga investor lebih suka membeli saham dengan nilai aktiva lancar yang tinggi dibandingkanperusahaan yang mempunyai nilai aktiva lancar yang rendah (Prihatini, R., 2009).

\subsection{Inflasi dan Hubungannya dengan Return Saham}

Inflasi adalah kecenderungan peningkatan harga produk-produk secara keseluruhan (Tandelin, E., 2010). Kenaikan harga dari satu atau dua macam barang saja tidak dapat dikatakan sebagai inflasi kecuali kenaikan tersebut membawa dampak terhadap kenaikan harga sebagian besar barang-barang lain. Inflasi tinggi biasanya dikaitkan dengan kondisi ekonomi yang terlalu aktif, dimana investasi dilakukan melebihi kebutuhan. Artinya permintaan produk yang melebihi kapasitas penawarannya, sehingga harga-harga cenderung naik. Inflasi yang terlalu tinggi juga akan menyebabkan penurunan daya beli uang dan mengurangi pendapatan riil yang diperoleh investor dari investasinya, sebaliknya jika tingkat inflasi suatu negara mengalami penurunan maka ini merupakan sinyal yang positif bagi investor seiring dengan turunnya resiko daya beli uang dan resiko penurunan pendapatan riil.

\subsection{Hipotesis} berikut :

Berdasarkan kerangka pemikiran, maka dapat dirumuskan hipotesis penelitian sebagai

1) Return Saham Industri Makanan dan Minuman di BEI periode 2008 s.d 2012 dipengaruhi oleh variabel ROA, DER, CR,inflasi dan kurs secara simultan.

2) Return Saham Industri Makanan dan Minuman di BEI periode 2008 s.d 2012 dipengaruhi oleh variabel ROA, DER, CR, Inflasi dan Kurs secara Parsial. 


\section{METODE PENELITIAN}

\subsection{Populasi dan Sampel}

Populasi dalam penelitian ini adalah Industri makanan dan minumansebanyak 19 perusahaan. Pengambilan sampel dilakukan dengan metodepurposive sampling, dengan kriteria :

a. Perusahaan yang tercatat di Bursa Efek Indonesia selama periode 2008 s.d 2012

b. Tersedia data laporan keuangan (ROA, DER, dan CR) selama kurun waktu penelitian periode 2008 s.d 2012

c. Tersedia data harga saham

Jumlah sampel Industri makanan dan minumanyang memenuhikriteria sebanyak 16 yang terdaftardi Bursa Efek Indonesia periode 2008 s.d 2012

\subsection{Jenis dan Sumber Data}

Jenis data yang digunakan dalam penelitian adalah data sekunder, yaitu data yang diperoleh dari pihak lain dalam bentuk yang sudah jadi dan dipublikasikan untuk umum. Beberapa sumber data yang digunakan dalam penelitian ini adalah yaitu inflasi dan kursselama periode 2008 s.d 2012 melalui internet dari jurnal Bank Indonesia; Jurnal Biro Pusat Statistik selama periode 2008 s.d. 2012; data Return Saham, ROA, DER dan CR berasal dari Indonesian Capital Market Directory(Anonim, 2013).

\subsection{MetodeAnalisis Data}

Penelitian ini menggunakan metode analisisregresi linier berganda. Pengujian asumsiklasik yang digunakan yaitu ujinormalitas, multikolinearitas, heteroskedastisitas dan autokorelasi. Sementara untuk menguji tingkatsignifikan variabel digunakan uji $\mathrm{F}$ dan uji T.Uji Fdigunakan untuk mengetahui apakahvariabel-variabel independent secara bersamasama (simultan) berpengaruhatau tidak terhadap variabel dependent.Uji $\mathrm{T}$ digunakan untuk mengetahuipengaruh dari setiap variabel independent.

\section{HASIL DAN PEMBAHASAN}

\subsection{Gambaran Umum Obyek Penelitian}

Obyek penelitian dalam penelitian ini adalah industri Makanan dan Minumanyang terdaftar di Bursa Efek Indonesia periode2008 s.d 2012.Dari total keseluruhan perusahaan yang ada, setelahmemenuhi kriteriasampling yang ditetapkan, maka diperoleh 16 perusahaan yang menjadi sampel penelitian. Daftar perusahaan-perusahaan yang memenuhi kriteria yang telah ditetapkan dapat dilihat pada Tabel 4.1.. 
Tabel 1. Daftar Sampel Perusahaan yang Memenuhi Kriteria

\begin{tabular}{|c|c|l|}
\hline No & Kode & \\
\hline 1 & ADES & PT. Akasha Wira International \\
\hline 2 & CEKA & PT. Cahaya Kalbar \\
\hline 3 & DAVO & PT. Davonas Abadi \\
\hline 4 & DLTA & PT. Delta Djakarta \\
\hline 5 & FAST & PT. Fast Food Indonesia \\
\hline 6 & INDF & PT. Indofood Sukses Makmur \\
\hline 7 & MYOR & PT. Mayora Indah \\
\hline 8 & MLBI & PT. Multi Bintang Indonesia \\
\hline 9 & PTSP & PT. Pioneerindo Gourmet Internasional \\
\hline 10 & PSDN & PT. Prasidha Aneka Niaga \\
\hline 11 & SKLT & PT.Sekar Laut \\
\hline 12 & STTP & PT. Siantar Top \\
\hline 13 & SMAR & PT. Sinar Mas Agro Resources And technology \\
\hline 14 & TBLA & PT. Tunas Baru Lampung \\
\hline 15 & AISA & PT. Tiga Pilar Sejahtera Food \\
\hline 16 & ULTJ & PT. Ultrajaya Milk Industry \& Trading Company \\
\hline
\end{tabular}

Sumber. Indonesian Capital Market Directory, (2013)

Data nilai tukar dan inflasi dalam penelitian inidiperoleh yang diperoleh dari Statistik Ekonomi dan Keuangan yangditerbitkan Bank Indonesia; sedangkan Return On Asset (ROA), Debt to Equity Ratio (DER), Current Ratio (CR) dan return saham diperoleh dariICMD (Indonesian Capital Market Directory) waktu tahunan periode 2008s.d 2012. Adapun data tentang dinamika pergerakan return sahampada Perusahaan Industri Makanan dan Minuman yang terdaftar di Bursa Efek Indonesia Periode 2008 s.d 2012 ditampilkan pada Gambar 4.1..

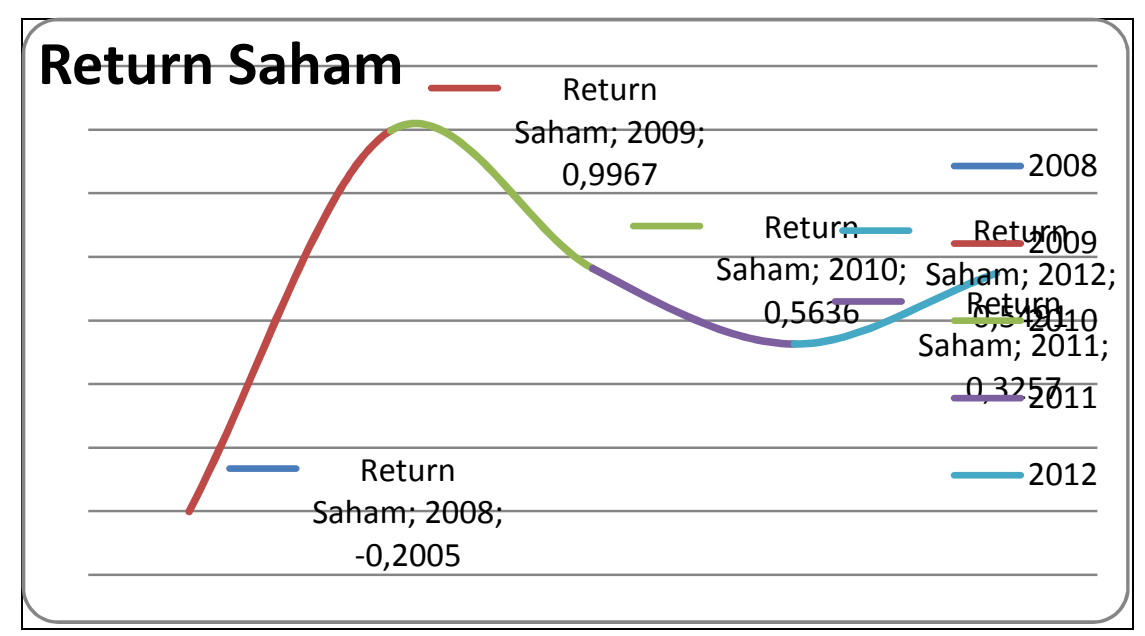

Gambar 1. Return Saham Pada Industri Makanan dan Minumanyang Terdaftar di Bursa Efek Indonesia Periode 2008 s.d 2012 
Dari Gambar 4.1. dapat terlihat bahwa besarnya return saham pada Industri Makanan dan Minumanyang terdaftar di Bursa Efek Indonesia periode 2008hingga 2009 return saham mengalami peningkatan. Pada periode 2009 hingga 2011 terus terjadi penurunan return saham.Pada Tahun 2012 return saham mengalami peningkatan lagi. Hal ini menunjukkan bahwa kondisi return saham pada periode penelitian mengalami fluktuasi.

Untuk memperoleh hasil statistik dilakukan dua uji yaitu uji $\mathrm{F}$ dan uji $\mathrm{t}$.

Uji $F$ digunakan untukmemeriksa pengaruh simultan variabel pelanggan independen terhadap variabel dependen sebagaimana pada Tabel. 2., berikut.

Tabel 2. Uji Simultan Variabel Penelitian

\begin{tabular}{|ll|r|r|r|r|r|}
\hline \multicolumn{2}{|l|}{ Model } & \multicolumn{1}{|c|}{$\begin{array}{l}\text { Sum of } \\
\text { Squares }\end{array}$} & df & Mean Square & F & Sig. \\
\hline 1 & Regression & 21.140 & 5 & 4.228 & 5.408 & $.000^{\mathrm{a}}$ \\
& Residual & 57.859 & 74 & .782 & & \\
& Total & 79.000 & 79 & & & \\
\hline
\end{tabular}

a. Predictors: (Constant), ZKURS, ZCR, ZINFLASI, ZROA, ZDER

b. Dependent Variable: ZRETURN

Sumber. Hasil olahan data, 2013.

Dari Tabel 2., di atas dapat diketahui bahwa $\mathrm{F}_{\text {hitung }}$ adalah sebesar 5,408 dengan nilai signifikansi 0,000.Halini membuktikan bahwa variabel-variabel independent secara bersamasama memiliki pengaruh yang signifikan terhadap variabel dependent. Karena probabilitas jauh lebih kecil dari 0,05 atau 5\%, maka model regresi dapat dikatakan bahwa ROA, DER, CR, Inflasi dan Kurs secara bersama-sama berpengaruh terhadap Return Saham Industri Makanan dan Minuman di BEI periode 2008-2012. BerartiHo ditolak dan Ha diterima, yang berarti juga variabel, ROA, DER CR, Inflasi dan Kurs secara simultan mempunyai pengaruh signifikan terhadap Return Saham.

Selanjutnya, peralatan statistik untuk memeriksa uji parsial digunakan tabel $\mathrm{t}$ sebagaimana pada Tabel 3., berikut.

Tabel 3. Uji Parsial Variabel Independen Penelitian

\begin{tabular}{|l|r|r|r|r|r|}
\hline \multirow{2}{*}{ Model } & \multicolumn{2}{|c|}{ Unstandardized Coefficients } & Standardized Coefficients & & \\
\cline { 2 - 5 } & \multicolumn{1}{|c|}{$\mathrm{B}$} & Std. Error & Beta & \multicolumn{1}{c|}{$\mathrm{t}$} & \multicolumn{1}{c|}{ Sig. } \\
\hline 1 (Constant) & $-1.537 \mathrm{E}-6$ & .099 & & .000 & 1.000 \\
ZROA & .250 & .105 & .250 & 2.369 & .020 \\
ZDER & .016 & .106 & .016 & .148 & .882 \\
ZCR & -.004 & .105 & -.004 & -.042 & .966 \\
ZINFLASI & -.408 & .104 & -.408 & -3.910 & .000 \\
ZKURS & .233 & .102 & .233 & 2.274 & .026 \\
\hline
\end{tabular}

Sumber. Hasil Olahan Data, 2013. 


\subsection{Pembahasan Hasil Penelitian}

\subsubsection{Pengaruh ROA Terhadap Return Saham}

Hipotesis yang diajukan menyatakan bahwa ROA berpengaruh signifikan terhadap return saham di Industri Makanan dan Minuman periode2008 s.d 2012. Dari hasil penelitian ini diperoleh nilai koefisien regresi sebesar 2,369 dengan $\alpha=0,020$ dengan signifikansi sebesar 0,020 dimana nilai signifikansi lebih kecil dari 5\% atau 0,05. Makadapatdisimpulkan (H0 ditolak atau H1 diterima) bahwa variabel ROA berpengaruh signifikan terhadap variabel perubahan return saham. Prihatini, R. (2009) dan Subalno (2009) yang menyatakan bahwa ROA berpengaruh signifikan terhadap variabel perubahan return saham

Pendapatan bersih dan modal saham yang dimiliki perusahaan mengakibatkan naik atau turunnya harga saham. Inisesuai dengan teori bahwa ROA merupakan tolak ukur profitabilitas, dimana para pemegang saham umumnya ingin mengetahui tingkat probabilitas modal saham dan keuntungan yang telah mereka tanam kembali dalam bentuk laba yang ditanam. Apabila saham perusahaan diperdagangkan di bursa, tinggi rendahnya ROA akan mempengaruhi tingkat permintaan di bursa dan harga jualnya.ROA juga menunjukkan tingkat pengembalian bersih yang diperoleh dari total aktivaperusahaan, sehingga semakin besar ROA maka makin efisien perputaran aset perusahaan dan semakin besar pula profit margin yang diperoleh perusahaan.

\subsubsection{Pengaruh DER Terhadap Return Saham}

Hipotesis yang diajukan menyatakan bahwa DER berpengaruh signifikanterhadapreturn saham di Industri Makanan dan Minuman periode 2008 s.d 2012. Dari hasil penelitian ini diperoleh nilai koefisien regresi sebesar 0,148 dengan $\alpha=0,882$ dengan signifikansi sebesar 0,882 dimana nilai signifikansi lebih besar dari 5\% atau 0,05. Maka dapat disimpulkan (H0 diterima atau H4 ditolak) bahwa variabel DER tidak berpengaruh signifikan terhadap variabel perubahan return saham. Hasil penelitian ini sejalan dengan penelitian Suherli, Michel (2005) dan Subalno (2009) yang menyatakan bahwa variabel DER tidak berpengaruh signifikan terhadap variabel perubahan return saham.

DER yang tinggi menunjukkan komposisi total hutang (hutang jangka pendek dan hutang jangka panjang) semakin besar apabila dibandingkan dengan total modal sendiri, sehingga akan berdampak pada semakin besarnya beban perusahaan terhadap pihak eksternal (para kreditur) dalam memenuhi kewajiban hutangnya. Peningkatan beban terhadap kreditur akan menunjukkan sumber modal perusahaan sangat tergantung dari pihak eksternal, serta semakin tingginya tingkat risiko suatu perusahaan. Hal ini akan mengurangi minat investor dalam menanamkan dananya di perusahaan yang bersangkutan. Penurunan minat investor ini berdampak pada penurunan harga saham, sehingga return perusahaan juga semakin menurun. DERmencerminkan risiko perusahaan yang relatif tinggi akibatnya para investor cenderung menghindari saham-saham yang memiliki nilai DER yang tinggi dan menyebabkan apresiasi dan depresiasi harga saham yang ujungnya berdampak pada return saham. Dalam hal ini yang menyebabkan DER tidak berpengaruh secara signifikan adalah bahwa tinggi rendahnya leverage perusahaan bukan semata-mata disebabkan oleh kinerja manajemen tetapi juga dipengaruhi faktor lain sehingga DER kurang diperhatikan investor dalam mengambil keputusan investasi.

Hasil penelitian mengindikasikan adanya pertimbangan yang berbeda dari beberapa investor dalam memandang DER. Oleh sebagian investor DER dipandang besarnya tanggung jawab perusahaan terhadap pihak ketiga yaitu kreditur yang memberikan pinjaman kepada perusahaan. Semakin besar nilai DER akan memperbesar tanggungan perusahaan. Namun 
demikian nampaknya beberapa investor justru memandang bahwa perusahaan yang tumbuh pasti akan memerlukan hutang sebagai dana tambahan untuk memenuhi pendanaan pada perusahaan yang tumbuh. Perusahaan tersebut memerlukan banyak dana operasional yang tidak mungkin dapat dipenuhi hanya dari modal sendiri yang dimiliki perusahaan. Kondisi ini menyebabkan kemungkinan berkembangnya perusahaan dimasa yang akan datang yang berujung pada meningkatnya return saham.

\subsubsection{Pengaruh CR Terhadap Return Saham}

Hipotesis yang diajukan bahwa CR berpengaruh signifikan terhadap return saham di Industri Makanan dan Minuman periode 2008 s.d 2012. Dari penelitian ini diperoleh nilai koefisien regresi sebesar -0,042 dengan $\alpha=0,966$ dengan signifikansi sebesar 0,966 dimana nilai signifikansi lebih besar dari 5\% atau 0,05. Makadapat disimpulkan $\left(\mathrm{H}_{0}\right.$ diterima atau $\mathrm{H}_{4}$ ditolak) bahwa variabel $\mathrm{CR}$ tidak mempunyai pengaruh signifikan terhadap variabel perubahan return saham. Hasil penelitian ini sejalan dengan penelitian Subalno (2009) yang menyatakan bahwa variabel CR tidak berpengaruh signifikan terhadap variabel perubahan return saham.

Hasil analisis ini mengindikasikan bahwa Informasi CR sebagaimana bisa diperoleh dari laporan keuangan tidak berpengaruh signifikan pada return saham industri makanan dan minuman. Semakin besar CRyang dimiliki menunjukkan besarnya kemampuan perusahaan dalam memenuhi kebutuhan operasionalnya terutama modal kerja yang sangat penting untuk menjaga performance kinerja perusahaan yang pada akhirnya mempengaruhi performance harga saham. Hal ini dapat memberikan keyakinan kepada investor untuk memiliki saham perusahaan tersebut sehingga dapat meningkatkan returnsaham. Namun menurut Ross, et.al (2010)dalam Geovanni Budialim (2013), CR dapat juga mengindikasi penggunaan uang kas dan aset jangka pendek lainnya yang tidak efisien. Karena pertentangan inilah investor tidak memasukkan CR dalam pertimbangan investasinya sehingga CR tidak berpengaruh signifikan terhadap return saham.

\subsubsection{Pengaruh Inflasi Terhadap Return Saham}

Hipotesis yang diajukan menyatakan bahwa inflasi berpengaruh signifikan terhadap return saham di Industri Makanan dan Minuman periode 2008 s.d 2012. Dari hasil penelitian ini diperoleh nilai koefisien regresi sebesar -3,910 dengan $\alpha=0,000$ dengan signifikansi sebesar 0,000 dimana nilai signifikansi lebih kecil dari 5\% atau 0,05. Makadapat disimpulkan (H0 ditolak atau H4 diterima) bahwa variabel inflasi mempunyai pengaruh signifikan terhadap variabel perubahan return saham.

Inflasi yang tinggi akan mengakibatkan penurunan harga saham, karena kenaikan harga barang secara umum. Kondisi ini mempengaruhi biaya produksi dan harga jual barang yang akan menjadi semakin tinggi. Harga jual tinggi menyebabkan menurunnya daya beli, dan akan mempengaruhi keuntungan perusahaan dan akhirnya harga saham mengalami penurunan (Tandelilin, 2001). Peningkatan harga barang dan bahan baku ini akan membuat biaya produksi tinggi, sehingga berpengaruh pada penurunan jumlah permintaan secara individual maupun menyeluruh.Penurunan jumlah permintaan ini pada akhirnya akan menurunkan permintaan terhadap produk perusahaan sehingga akan berpengaruh pada return yang diterima perusahaan. Ekspektasi laju inflasi yang tinggi akan mendorong masyarakat untuk mengalihkan aset finansial yang dimilikinya menjadi aset riil, seperti tanah, rumah, dan barang-barang konsumsi lainya. Begitu pula sebaliknya ekspektasi laju inflasi yang rendah akan memberikan insentif terhadap masyarakat untuk menabung serta melakukan investasi pada sektor sektor produktif. Inflasi merupakan suatu variabel ekonomi makro yang dapat 
merugikan suatu perusahaan. Pada dasarnya inflasi yang tinggi tidak disukai oleh para pelaku pasar modal karena akan meningkatkan biaya produksi, yang akan berakibat buruk terhadap harga dan pendapatan. Para pelaku pasar modal lebih memandang inflasi sebagai suatu resiko yang harus dihindari. Pemilik saham dan pelaku pasar modal akan lebih suka melepas saham yang mereka miliki ketika inflasi tinggi. Hasil temuan ini mendukung penelitian Boucher (2004) dalam Tatik (2013) yang menyatakan bahwa inflasi berpengaruh signifikan terhadap returnsaham. Tingkat inflasi yang tinggi akan menurunkan tingkat profitabilitas perusahaan. Turunnya profit perusahaan adalah informasi yang buruk bagi investor yang akan menurunkan harga saham dan akan menyebabkan return saham menurun pula.

Hal ini menguatkan teori kuantitas yang menyatakan bahwa harga barang berbanding lurus dengan jumlah uang yang beredar.Teori ini menyatakan bahwa terjadinya inflasi disebabkan oleh satu faktor yaitu kenaikan uang yang beredar. Inflasi akan cenderung meningkatkan biaya produksi dari perusahaan. Artinya, margin keuntungan dari perusahaan menjadi lebih rendah dan dampak lebih lanjut menjadikan harga sahamnya di bursa efek menjadi menurun. Tingginya inflasi akan mengurangi nilai keuntungan dan juga mengurangi daya beli modal investasinya. Dengan demikian jika angka inflasi naik, maka harga saham akan menurun. Hal ini akan diikuti oleh penurunan return saham.

\subsubsection{Pengaruh Kurs Terhadap Return Saham}

Hipotesis yang diajukan bahwa kurs berpengaruh signifikan terhadap returnsaham di Industri Makanan dan Minuman periode 2008 s.d 2012. Dari hasil penelitian diperoleh nilai koefisien regresi sebesar 2,274 dengan $\alpha=0,026$ dengan signifikansi sebesar 0,026 dimana nilai signifikansi lebih kecil dari 5\% atau 0,05. Maka dapat disimpulkan (H0 ditolak atau H4 diterima) bahwa variabel kurs mempunyai pengaruh signifikan terhadap variabel perubahan return saham. Hasil penelitian sejalan dengan penelitian Prihatini, R., (2009).

Penelitian ini memperlihatkan bahwa variabel kurs pada periode 2008-2012, menunjukkan pengaruh signifikan.Hal ini dapat terjadi karena kurs tidak begitu tinggi atau hanya merangkak dari Tahun 2008-2012.Depresiasi nilai mata uang asing menandakan bahwa neraca perdagangan positif, meningkatnya komoditi ekspor mengakibatkan kurs rupiah menguat. Dengan menguatnya kurs rupiah sebagai apresiasi dari mata uang rupiah memberikan sinyal dalam berinvestasi, hal ini diiringi dengan meningkatnya harga saham dan akan berdampak pada return saham yang diharapkan oleh investor.

Selanjutnya, untuk mengetahui kemampuan variabel independen menjelaskan variasi perubahan variabel dependen dapat ditunjukkan oleh $\mathrm{R}^{2}$. Dari hasil penelitian diketahui bahwa $\mathrm{R}^{2}$ sebesar sebesar $21,80 \%$ dari variasi atau perubahan yang terjadi pada Return Saham Industri Makanan dan Minuman di BEI selama periode 2008 s.d 2012 terbukti dapat dijelaskan oleh kelima variabel independen tersebut, sedangkan sisanya sebesar 0,782 atau $78,20 \%$ tidak dijelaskan oleh variabel yang diteliti, dijelaskan oleh variabel lainnya yang tidak dimasukkan kedalam model regresi gabungan dalam penelitian ini.

\subsection{Kesimpulan}

\section{KESIMPULAN DAN SARAN}

Berdasarkan hasil penelitian dan pembahasan dapat disimpulkan sebagai berikut:

1. Secara simultan Variabel ROA, DER, CR Inflasi dan kurs mempunyai pengaruh yang signifikan terhadap Return Saham Industri Makanan dan Minuman di Bursa Efek Indonesia Periode 2008 s.d. 2012. 
2. Secara Parsial Variabel ROA, Inflasi, Kurs mempunyai pengaruh yang signifikan terhadap Return Saham Industri Makanan dan Minuman di Bursa Efek Indonesia Periode 2008 s.d. 2012. Sedangkan variabel DER dan CR tidak berpengaruh signifikan terhadap Return Saham Industri Makanan dan Minuman di Bursa Efek Indonesia Periode 2008 s.d. 2012.

\subsection{Saran}

Dari kesimpulan diatas, maka dapat diberikan rekomendasi sebagai berikut:

1. Apabila investor ingin berinvestasi pada Industri Makanan dan Minuman di Bursa Efek Indonesia dalam menentukan tingkat pengembalian saham (return saham) harus lebih memperhatikan dan mempertimbangkan faktor-faktor yang mempengaruhi return saham seperti ROA, Inflasi dan Kurskarena ketiga faktor tersebut terbukti berpengaruh signifikan.

2. Dalam penelitian mendatang perlu menambahkan menambah rasio keuangan lainnya sebagai variabel independen, karena sangat dimungkinkan rasio keuangan lain yang tidak dimasukkan dalam penelitian ini berpengaruh kuat terhadap return saham.

\section{DAFTAR PUSTAKA}

Anonim, 2012. Indonesian Capital Market Directory (ICMD). Tahun 2008-2012, Jakarta .

Arista, D., 2012.Analisis Faktor-faktor yang mempengaruhi return saham (Kasus pada Perusahaan Manufaktur yang Go Public di BEI periode tahun 2005 - 2009). Jurnal Ilmu Manajemen dan Akuntansi Terapan, Vol 3 Nomor 1, Mei 2012.

Bank Indonesia, 2008 - 2011.Indonesia Financial Statistik. BI, Jakarta, www. BI.co.id

Budialim, G., 2013. Pengaruh Kinerja Keuangan Dan Resiko Terhadap Return Saham

Perusahaan Sektor Consumer Goods 2007-201. Jurnal Ilmiah Mahasiswa Universitas

Surabaya, Vol.2. No.1. 2013.

Ervita S., dan Ratna, J., 2013. Pengaruh Inflasi Dan Tingkat Suku

Bunga Terhadap Return Saham PT Indofood Sukses Makmur Tbk (2009-2011). Jurnal Mahasiswa.

Gunawan, 2012.Pengaruh Rasio Camel, Inflasi dan Nilai tukar terhadap Return Saham (Studi

Empiris: Bank yang terdaftar di BEI). Skripsi. Universitas Diponegoro. Semarang.

Halim, A. 2005. Analisis Investasi. Edisi kedua. Salemba Empat. Jakarta.

Husna, S. 2009. Dasar-Dasar Teori Portofolio dan Analisa Sekuritas. Edisi Keempat. UPP STIM YKPN. Yogyakarta.

Jogiyanto H.M., 2000. Teori Portfolio dan Analisa Investasi, BPFE: Yogyakarta, Edisi 2

Prasetio, W. A., 2013. Analisis Pengaruh Variabel Makro-Ekonomi dan Rasio Keuangan Perusahaan terhadap Return Saham (Studi Kasus padaSub-Sektor Komponen dan Otomotif yang Terdaftar Di Bursa Efek Indonesia).Jurnal.

Prihatini, R., 2009. Analisis Pengaruh Inflasi, Kurs ROA, DER dan CR Terhadap Return Saham (Studi Kasus Saham Industri Real Estate and Property yang Terdaftar di Bursa Efek Indonesia Periode 2003 - 2006). Tesis. Universitas Diponegoro.

Sukirno, S., 1997. Ekonomi Pembangunan, Edisi 2, Yogyakarta : BPFE.

Sodikin, A., 2007. Variabel makro ekonomi yang mempengaruhi return saham. Jurnal Manajemen, Vol. 6, No. 2, Mei 2007.

Subalno. 2009. Analisis Pengaruh Faktor Fundamental dan Kondisi Makro Ekonomi Terhadap Return Saham. Universitas Diponegoro. 
Suharli, M., 2005,Studi Empiris Terhadap Dua Faktor Yang Mempengaruhi Return Saham pada Industri Food \& Beverage di BEJ. Jurnal Akuntansi dan Keuangan. Vol. 7, No. 2, November

Sutrisno, 2009.Manajemen Keuangan.Ekonisia.Yogyakarta.

Tatik. 2013. Inflasi, Kurs, Laverage, Profitabilitas dan Return Saham Perusahaan Farmasi Go Publik BEI 2008-2012. Jurnal Ilmu Manajemen. Vol 1.

Tandelilin, E., 2010. Portofolio dan Investasi. Kanisius. Yogyakarta

Tandelilin, E., 2001. Portofolio dan Investasi.Kanisius. Yogyakarta 